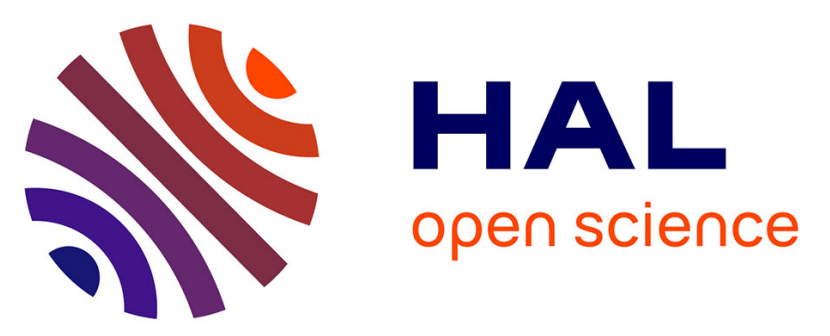

\title{
Observatory of Transfers in the Vadose Zone "O-ZNS" (in Orléans, France): Instrumentation strategy and installation of fiber optic sensors (DTS, DAS and DSS)
}

Bouamama Abbar, Arnaud Isch, Céline Mallet, Clara Jodry, Gautier Laurent, Mohamad Abbas, Mohamed Azaroual

\section{To cite this version:}

Bouamama Abbar, Arnaud Isch, Céline Mallet, Clara Jodry, Gautier Laurent, et al.. Observatory of Transfers in the Vadose Zone "O-ZNS" (in Orléans, France): Instrumentation strategy and installation of fiber optic sensors (DTS, DAS and DSS). vEGU21: Gather Online, Apr 2021, Online, France. 10.5194/egusphere-egu21-8639 . hal-03554528

\author{
HAL Id: hal-03554528 \\ https://hal.science/hal-03554528
}

Submitted on 3 Feb 2022

HAL is a multi-disciplinary open access archive for the deposit and dissemination of scientific research documents, whether they are published or not. The documents may come from teaching and research institutions in France or abroad, or from public or private research centers.
L'archive ouverte pluridisciplinaire HAL, est destinée au dépôt et à la diffusion de documents scientifiques de niveau recherche, publiés ou non, émanant des établissements d'enseignement et de recherche français ou étrangers, des laboratoires publics ou privés. 


\title{
EGU21-8639
}

https://doi.org/10.5194/egusphere-egu21-8639

EGU General Assembly 2021

(c) Author(s) 2022. This work is distributed under

the Creative Commons Attribution 4.0 License.

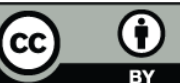

\section{Observatory of Transfers in the Vadose Zone "O-ZNS" (in Orléans, France): Instrumentation strategy and installation of fiber optic sensors (DTS, DAS and DSS)}

\author{
Bouamama Abbar ${ }^{1}$, Arnaud Isch ${ }^{1}$, Céline Mallet ${ }^{1}$, Clara Jodry $^{2}$, Laurent Gautier ${ }^{1}$, Mohamad \\ Abbas $^{1}$, and Mohamed Azaroual ${ }^{1}$ \\ ${ }^{1}$ Institut des Sciences de la Terre d'Orléans, Université d'Orléans, France (bouamama.abbar@cnrs-orleans.fr) \\ ${ }^{2}$ École et Observatoire des Sciences de la Terre, Université de Strasbourg, France
}

The geological and petrophysical properties of the Vadose Zone (VZ) play a major role in the reactive transport of contaminants and fluid dynamics in fractured media and karstic hydrosystems. The mass and heat transfers through the VZ are governed by numerous complex and coupled processes, which control the fate of pollutants and influence the quality of groundwater resources. The current scientific research aimed at deciphering these hydrological and biogeochemical processes thanks to multi-scale laboratory experimentations and field observations. In order to acquire observation data over a wide range of spatial (nm- to $\mathrm{km}-$ ) and temporal (minutes to decades) scales, an Observatory of transfers in the Vadose Zone (O-ZNS) is being developed at Villamblain (Orléans, France) in an agricultural field. The O-ZNS project consists of an access well with a diameter of $4 \mathrm{~m}$ and a depth of $20 \mathrm{~m}$ surrounded by several boreholes which will provide access to the entire VZ of the Beauce aquifer. The main target of the O-ZNS project is to acquire high resolution data on the reactive transfers of mass and heat in the $V Z$, in order to follow in situ and in real time the highly coupled physical, chemical, and biological processes taking place over the long term and at different various scales.

To meet the scientific objectives of the project, several sensors and environmental monitoring techniques are being considered as part of the instrumentation of the O-ZNS site. The preliminary geological, geochemical, and hydrogeological investigations conducted at the laboratory scale and coupled with a multi-methods geophysical sounding undertaken at the field scale generated valuable information on the lithological and hydraulic properties of the highly heterogeneous VZ facies. Based on these results, a first estimation of the mean water travel time of 29 years for an inert solute to reach the water table level (15 m deep) was given.

In this context, three distributed optical fiber sensors (temperature "DTS", deformation "DSS", and acoustic "DAS") were installed in July 2020 along three boreholes surrounding the main observatory well and were connected to a data center. These sensors will allow the monitoring of fluid circulation, the rock fractures characterization, and the micro-movements detection in the VZ of the Beauce aquifer. Many innovative hydrogeological solutions are also being considered for the monitoring of fluids and solutes transport in VZ. These sensors include: water content probes 
for deep VZ materials, multi-level water sampler systems, and new generation of lysimeters allowing the study of contaminants transfer at an intermediate scale between laboratory and field. A latest-generation multiparameter probe will also be installed in February 2021 in the O-ZNS piezometer to monitor the variations of the water level and the quality of the groundwater. To complete these sensors, geophysical imagery will be deployed at different scale to link all parameters together in a 3D model.

This whole set of devices will provide a better understanding of the mass and heat transfer processes within the whole VZ column of the Beauce aquifer and some of the key compartments of the critical zone. 